\title{
Evaluation of a sexuality education program for young adolescents in Jamaica
}

\author{
Elizabeth Eggleston, ${ }^{1}$ Jean Jackson, ${ }^{2}$ Wesley Rountree, ${ }^{1}$ \\ and Zhiying Pan ${ }^{1}$
}

ABSTRACT Despite their increasing numbers, few of the sexuality education and pregnancy prevention programs in developing countries have been evaluated. This study, conducted in 1995-1997, assesses the impact of a school-based sexuality education program, the Grade 7 Project, on 945 Jamaican seventh graders (aged 11-14) and their initiation of sexual activity and use of contraception at first intercourse, as well as the knowledge and attitudes that influence their behaviors. Using a quasi-experimental design, the study measured the effects of the Grade 7 Project when the nine-month intervention was completed (short term) and one year after that (long term). Multivariate logistic regression analysis indicated that the project had no effect on initiation of sexual activity, but it had a positive short-term impact on use of contraception at first intercourse $(\mathrm{P}=.08)$; adolescents in the intervention group were more than twice as likely to use contraception. The project also had a positive short-term influence on several aspects of the adolescents' knowledge of and attitudes about sexuality and pregnancy. The modest impact of the Grade 7 Project is encouraging, as school-based sexuality education programs of limited duration rarely have a long-term impact. Moreover, competing socioeconomic and cultural forces in Jamaica encourage early sexuality and parenthood among adolescents. The use of more participatory teaching methods and smaller class sizes might strengthen the Grade 7 Project and enhance its impact.

Over the past several decades, programs to prevent pregnancy and sexually transmitted diseases (STDs) among adolescents have proliferated in both the United States of America and in developing countries. In the United States, researchers have evalu-

\footnotetext{
1 Family Health International, Research Triangle Park, North Carolina, United States of America. Send correspondence to: Elizabeth Eggleston, Population Leadership Program, 2168 Shattuck Ave., Suite 300, Berkeley, CA 94704, United States of America.

2 Fertility Management Unit, Department of Obstetrics \& Gynaecology, University of the West Indies, Mona, Kingston, Jamaica.
}

ated the effectiveness of many of these programs (1-5, for example). However, there are few reports on the effectiveness of sexuality education and pregnancy prevention programs in Latin America and the Caribbean.

In the Caribbean nation of Jamaica, there is a particularly pressing need to evaluate sexuality education and pregnancy prevention programs. The country's adolescent fertility rate has increased in recent years and, at 112 per 1000 women aged 15-19, is among the highest in the region. Before they reach the age of $20,37 \%$ of Jamaican women have been pregnant at least once, and $81 \%$ of these pregnancies are unplanned. Sexual activity begins at an early age for many Jamaicans. Among those 15 to 17 years old, 38\% of females and $64 \%$ of males reported having had sexual intercourse. The younger that adolescents begin sexual activity, the less likely they are to use contraception, thus increasing their risk of pregnancy and STDs (6).

Of the Jamaican young adults aged $15-24,76 \%$ of the males and $86 \%$ of the females report they have taken a course in family life or sex education (6), but virtually none of these courses has been evaluated $(7,8)$. Family life 
education in Jamaica varies widely from school to school, and instructors often do not provide frank, detailed information about sexuality and pregnancy prevention (7). As in many other countries, Jamaican family life educators often stress the importance of waiting until marriage for sexual activity, despite the fact that only $16 \%$ of Jamaican women of reproductive age are legally married (9).

Now is an opportune time to provide information about the effectiveness of sexuality and family life education programs in Jamaica. Policymakers and health care providers have grown increasingly alarmed over the levels of pregnancy and STDs among adolescents and are seeking new solutions to these problems (10). Improving adolescent reproductive health and reducing teenage pregnancy rates are now among Jamaica's stated top health priorities. The Government of Jamaica has announced plans to standardize and strengthen the family life education program and improve access to reproductive and family planning services for adolescents $(11,12)$.

The objective of this study was to assess the impact that a sexuality and family life education program known as the Grade 7 Project had on young adolescents (aged 11-14) and on their initiation of sexual activity and contraceptive use, as well as the reproductive knowledge and attitudes that were likely to influence these behaviors. Because the Grade 7 Project was implemented in schools typical of those attended by over half of Jamaican seventh graders, the results of this longitudinal study provide important evidence regarding the project's potential effectiveness in delaying first sexual intercourse and encouraging the use of contraception among a wider population of young adolescents.

\section{DATA AND METHODS}

\section{The Grade 7 Project}

The Grade 7 Project is a sexuality and family life education program for young adolescents designed and implemented by the Women's Centre of Jamaica Foundation. The Women's Centre is best known for its Program for Adolescent Mothers, and development of the Grade 7 Project was informed by the Centre's experience providing educational, health, and social services to pregnant adolescents and adolescent mothers $(13,14)$. The Grade 7 Project can be considered both an "abstinence promotion" and a "risk reduction/safer sex" intervention. Its stated objectives are to delay initiation of sexual intercourse among young adolescents and encourage the use of family planning among those who choose to become sexually active, by providing information about sexuality, reproductive health, and family planning, and by influencing attitudes about sex, family planning, and adolescent pregnancy.

The Grade 7 Project was implemented in ten "new secondary" and "all-age" schools across Jamaica in 1994-1996, in place of the sexuality education curricula normally offered. About $60 \%$ of Jamaican youth aged 12-14 attend all-age or new secondary schools, which are secondary institutions that generally do not prepare students for a university education (15). Adolescents at these schools, who tend to be from lower socioeconomic strata, have performed poorly on a placement test at the end of elementary school and failed to gain entrance to a traditional high school or technical high school.

Female educator-counselors, employees of the Women's Centre, conducted Grade 7 Project sessions once per week throughout the academic year (about nine months). The sessions were coeducational, and each lasted approximately 45 minutes. Class size varied from 30 to 60 students. Due in part to the large class size, educatorcounselors gave classroom lectures, supported by visual aids and question-and-answer sessions. In addition, small group discussions were held during some sessions. Educator-counselors provided students with frank, detailed information about reproductive anatomy and physiology, STDs, and contraceptive methods. They clarified myths about family planning, STDs, and pregnancy and explored the risks and consequences of sexual activity and pregnancy among young adolescents. Also discussed were the messages that adolescents receive from their peers, family, and the media about sex and adolescent parenthood.

\section{Research design}

The primary purpose of the evaluation was to assess the impact of the Grade 7 Project on initiation of sexual intercourse, use of contraception at first intercourse, and knowledge and attitudes that may be related to these behaviors. Since the Grade 7 curriculum was already in place in schools before the evaluation was developed, students could not be randomly assigned to intervention or comparison groups. Therefore, a quasi-experimental study design was used to evaluate the intervention. First, five of the 10 schools participating in the Grade 7 Project were selected for study participation. These five schools were chosen because they were located in different geographic areas of Jamaica and represented both urban and rural locations. Next, five schools were selected to form a matched comparison group. Each comparison group school was geographically close to a Grade 7 Project school and similar in terms of academic caliber, number of students, and student demographics. Study participants at comparison group schools were exposed to a variety of sexuality and family life education curricula other than the Grade 7 Project. The researchers did not desire a no-treatment comparison group because virtually all Jamaican secondary schools have some type of sexuality education instruction. No member of the evaluation team was affiliated in any way with the Grade 7 Project or the Women's Centre of Jamaica Foundation.

Within the 10 schools selected for study participation, all seventh grade students were asked to participate in the study. No student refused, but approximately $3 \%$ were absent when the 
survey was first conducted. All the students' parents were given the option of refusing to allow their children to participate in the study, but none did so.

\section{Sample}

A total of 945 students, 490 girls and 455 boys, completed a baseline questionnaire in September 1995. Ninetytwo percent of these students completed a posttest questionnaire in June 1996 , and $76 \%$ of the original sample completed a second posttest in June 1997. There was no difference between adolescents lost to follow-up and those who remained in the study in terms of school attended or urban vs. rural school location. Between baseline and posttest 1 , boys were significantly more likely than girls to be lost to follow-up, $10 \%$ vs. $5 \%$. However, there was no sex difference in loss to follow-up at post-test 2 . Between posttest 1 and posttest 2, adolescents in the comparison group were somewhat more likely than Grade 7 project participants to be lost, $27 \%$ vs. $20 \%$.

\section{Data collection instruments}

Study participants were surveyed three times during the study period. In September 1995, before the Grade 7 Project was implemented, students filled out the baseline questionnaire. They completed the posttest questionnaires in June 1996, shortly after the Grade 7 Project ended, and in June 1997, a year after the project ended. This allowed the measurement of both short-term and long-term effects.

The questionnaire was reviewed by the Women's Centre and several professionals in the field of adolescent reproductive health research. The questionnaire and methods of administering it were pretested twice, among seventh graders at schools similar in academic caliber and student demographic composition to schools receiving the Grade 7 Project. At the first pretest, one group of students completed a self-administered question- naire, while an interviewer guided a second group through the questionnaire. In addition, discussion sessions were held with small groups of students to solicit their understanding of and reactions to the questionnaire items. The pretest determined that a large proportion of the students could not read and write well enough to complete self-administered questionnaires, and many had difficulty answering items asking them to indicate their level of agreement on a five-point Likert scale. The students' low literacy also limited the number of written questions they could answer in a reasonable time period. After the first pretest, the questionnaire was revised considerably. The second pretest, conducted at a different school, resulted in only minor changes to the questionnaire.

The researchers took care to assure respondents that the information they provided on the questionnaires would remain confidential. Adolescents were assured that neither teachers, classmates, or parents would be able to learn of their responses. Names and other identifying information were kept separate from the questionnaire. Confidential identification numbers were used to match the baseline questionnaire with the two posttests. During study implementation, students filled out the questionnaires in singlesex groups of eight to 15 , in a classroom setting. Due to the poor reading skills of many adolescents, an interviewer read aloud each question and its possible responses to the students, who were asked to follow along on the written forms. There were no skip patterns on the questionnaire; every student answered every question. "I have not had sex" was a possible response to all questions regarding sexual experience. This prevented students from gauging the extent of their classmates' sexual experience by observing who was answering a particular question.

\section{Measures}

To develop the questionnaire items, we drew on previous research in the field and discussions with the Grade 7
Project educator-counselors and other Women's Centre staff. The main outcome of interest was whether an adolescent had become sexually active subsequent to the intervention. Additionally, among adolescents who did become sexually active in this time period, we were interested in whether they used a method of contraception at first intercourse. Before reading the questionnaire items pertaining to sexual activity, interviewers defined sexual intercourse aloud to students in simple terms as meaning heterosexual vaginal intercourse ("when a boy or man puts his penis in a girl's or woman's vagina"); the Grade 7 Project curriculum did not include discussion of homosexuality or such other expressions of sexuality as oral sex, anal sex, and mutual masturbation. Family planning was defined aloud as "things people do to avoid getting pregnant when they have sexual intercourse, like using birth control pills or a condom."

We also measured a range of variables thought to shape adolescent decision-making regarding sexual behavior. These included measures of household composition, religiosity, and experience with alcohol and marijuana. A range of questions assessed adolescents' knowledge and attitudes. All knowledge and attitude questionnaire items addressed issues covered by the Grade 7 Project curriculum. Adolescents responded "true," "false," or "I don't know" to most knowledge items; one item was multiple-choice. Twelve items with which adolescents agreed or disagreed measured attitudes about sexual activity, family planning, and teen pregnancy and parenthood.

A small number of adolescents' questionnaire responses contained discrepancies regarding whether they had experienced sexual intercourse. For example, a boy might report that he had not had sex, but his responses to subsequent questions indicated that he had first had sex at age 12 and his partner was 13 . If it was unclear whether an adolescent had experienced sexual intercourse, his or her responses about sexual experience (but not other topics) were excluded from analysis. In the baseline survey, $1.8 \%$ 
of adolescents had discrepancies regarding sexual activity; fewer than $1 \%$ gave discrepant answers on posttest 1 and posttest 2 .

\section{Statistical analysis}

As a preliminary step, we conducted bivariate analysis using chi-square tests of association to compare adolescents lost to follow-up to those who remained in the study. Next, we compared the intervention and comparison groups for baseline sociodemographic information and sexual experience using chi-square analyses for categorical variables and $t$ tests for continuous variables. We then compared the intervention and comparison groups' responses to dichotomized measures of knowledge and attitudes at each time point.

Multiple logistic regression analysis using generalized estimation equations (GEE) as an estimating method was conducted to assess jointly the short-term and long-term effects of the Grade 7 Project on adolescents' knowledge and attitudes, while controlling for gender and the passage of time. GEE accounts for the correlation of multiple responses (at different points in time) from a single respondent. We defined short term as immediately following the intervention and long term as one year after the intervention had ended.

We conducted logistic regression to evaluate the effect of the Grade 7 Project on initiating sexual activity and using contraception during first sexual intercourse, while controlling for other factors associated with adolescent reproductive behavior. Separate regression models were fitted for the two time periods under study, baseline to posttest 1 and baseline to posttest 2 . The analyses of sexual activity and use of contraception were conducted only among adolescents who reported in the baseline survey that they had not experienced first intercourse and who had no missing information for the outcome or independent variables. In all analyses, a $P$ value of less than .05 was considered statistically significant.

TABLE 1. Baseline means and percentages for background characteristics of adolescents in intervention and comparison groups, Grade 7 Project evaluation, Jamaica, 1995-1997 $(n=945)^{\mathrm{a}}$

\begin{tabular}{lcc}
\hline \multicolumn{1}{c}{ Characteristic } & $\begin{array}{c}\text { Intervention } \\
(n=426)\end{array}$ & $\begin{array}{c}\text { Comparison } \\
(n=519)\end{array}$ \\
\hline Mean age (years) & $12.2^{*}$ & $12.1^{*}$ \\
\% male & 50.7 & 46.1 \\
\% living with two parents & 36.3 & 37.2 \\
\% attending church at least once per week & 61.7 & 61.6 \\
\% ever used alcohol & $38.0^{*}$ & $46.1^{*}$ \\
\% ever used marijuana & 6.9 & 7.8 \\
\% reporting sexual experience & 34.2 & 33.1 \\
\hline
\end{tabular}

a The " $n$ " figures apply to total number of respondents in each group and may vary slightly for particular characteristics due to item nonresponse.

* indicates that the difference between the intervention and comparison groups was statistically significant at the $P<0.05$ level.

\section{RESULTS}

\section{Sociodemographic characteristics and sexual experience}

All adolescents in the study were from families of low or lower-middle socioeconomic status and attended schools of relatively poor academic caliber. At baseline, all were in seventh grade, and their ages ranged from 11 to 14 years; the mean age was just over 12 years (Table 1 ). There were no statistically significant baseline differences between adolescents in the Grade 7 Project and those in the comparison group in terms of household composition (living with two parents or not), church attendance, or marijuana use (Table 1). Comparison group adolescents were more likely than intervention group adolescents to have experimented with alcohol.

There was no significant difference between intervention and comparison groups regarding sexual experience. At baseline, approximately one-third of both groups said they had already experienced sexual intercourse (Table $1)$. Reports of sexual experience differed dramatically between boys and girls; at baseline, $6 \%$ of girls versus $64 \%$ of boys claimed to be sexually experienced (data not shown).

\section{Reproductive knowledge}

In general, in the surveys the students in the intervention and comparison groups demonstrated a very low level of knowledge about reproductive matters (Table 2). On the surveys at all three points in time, only one of seven knowledge items ("using a condom is a good way to avoid getting a sexually transmitted disease") was answered correctly by the majority of adolescents.

Multivariate analysis showed that the Grade 7 Project had a positive short-term effect on several knowledge items. At posttest 1, when the adolescents were finishing seventh grade, knowledge scores on four of seven items had increased significantly more among youth in the Grade 7 Project than among those in the comparison group (as indicated by the positive coefficients for the variable "Group*Posttest 1" in Appendix Table A1). Knowledge on one item (time during menstrual cycle when pregnancy is most likely) increased significantly more among the comparison group than the intervention group.

The project's positive effects on knowledge were not sustained over time. At posttest 2, one year after the adolescents finished participating in the Grade 7 Project, there was little 
TABLE 2. Percentage of adolescents in intervention and comparison groups responding correctly to knowledge items, by timing of survey, Grade 7 Project evaluation, Jamaica, 1995-1997

\begin{tabular}{|c|c|c|c|c|c|c|}
\hline \multirow[b]{2}{*}{ Item } & \multicolumn{2}{|c|}{ Baseline } & \multicolumn{2}{|c|}{ Posttest 1} & \multicolumn{2}{|c|}{ Posttest 2} \\
\hline & $\begin{array}{c}\text { Intervention } \\
(n=426)^{\mathrm{a}}\end{array}$ & $\begin{array}{c}\text { Comparison } \\
(n=519)\end{array}$ & $\begin{array}{l}\text { Intervention } \\
(n=392)\end{array}$ & $\begin{array}{c}\text { Comparison } \\
(n=476)\end{array}$ & $\begin{array}{c}\text { Intervention } \\
(n=339)\end{array}$ & $\begin{array}{c}\text { Comparison } \\
(n=379)\end{array}$ \\
\hline Pregnancy is possible at first intercourse & 29.9 & 30.0 & $44.4^{*}$ & 34.7 & 45.1 & 38.4 \\
\hline Condoms protect against STDs & 63.3 & 65.8 & $75.5^{*}$ & 65.5 & 67.6 & 66.8 \\
\hline Standing while having sex prevents pregnancy & 24.0 & 20.9 & $45.2^{*}$ & 20.7 & $45.2^{*}$ & 27.7 \\
\hline Drinking Coke or Pepsi after having sex prevents pregnancy & 22.4 & 18.1 & $39.6^{*}$ & 19.9 & 37.5 & 23.3 \\
\hline
\end{tabular}

evidence of differences in knowledge change between the two groups (as indicated by the nonsignificant coefficients for "Group*Posttest 2" for most items in Table A1). While knowledge on one item ("having sex while standing prevents pregnancy") had increased significantly more among Grade 7 Project participants than among comparison group youth, knowledge levels increased more among the comparison group on another item (time during menstrual cycle when pregnancy most likely).

\section{Attitudes}

Sexual activity attitudes. On the surveys at all three points in time, most young adolescents disapproved of a person their age having sexual intercourse outside an established romantic relationship (Table 3). On the other hand, many felt that sex was required or expected in certain situations. Onethird to one-half of all the students shared the opinion that "if you really love your boyfriend or girlfriend, you should have sex with him/her." Many adolescents also thought that a girl should have sex with a boy who spent a lot of money on her.

Multivariate analyses indicated that the Grade 7 Project had a statistically significant short-term influence on several attitudes about sexual activity. For three of four items (all except "it is okay for a boy to have sex with a girl who is not his steady girlfriend"), the attitudes of adolescents in the Grade 7 Project were likely to become more conservative by posttest 1 , compared to comparison group adolescents (as indicated by the positive coefficients for the variable "Group*Posttest 1" in Appendix Table A2). However, by posttest 2, differences in attitudes about sex between the two groups were no longer evident.

Family planning attitudes. Adolescents displayed mixed attitudes toward contraception and family planning (Table 3). A large majority agreed that using oral contraceptives is responsible behavior and that a boy who uses a condom is treating his girlfriend with respect. However, many adolescents also associated contraception with promiscuity, agreeing with statements that condoms and oral contraceptives are used only by boys and girls who have multiple sexual partners.

Multivariate analyses showed that the Grade 7 Project did not have a significant effect on attitudes about family planning, in either the short term or the long term (as indicated by the non- significant coefficients for the variables "Group*Posttest 1" and "Group* Posttest 2" in Appendix Table A3).

Parenthood attitudes. Most respondents expressed negative attitudes toward adolescent pregnancy and parenthood (Table 3). At posttest 2 (the end of eighth grade), only $15 \%-17 \%$ agreed that a girl should have a baby as a teenager to prove her fertility. Similarly, few adolescents thought that a girl or boy their age was responsible enough to be a parent. As adolescents matured-and perhaps as teen pregnancy became more relevant to their lives-they became less likely to express positive attitudes about adolescent pregnancy.

The Grade 7 Project had a shortterm influence on two of the three measures of attitudes toward adolescent parenthood. Multivariate analysis indicated that between baseline and posttest 1, adolescents in the Grade 7 Project were significantly less likely than those in the comparison group to adopt the views that a teenage girl should have a baby to prove her fertility, or that a girl their age is responsible enough to be a mother (as indicated by the negative coefficients for the variables "Group*Posttest 1" and "Group*Posttest 2" in Appendix Table 
TABLE 3. Percentage of adolescents in intervention and comparison groups agreeing with statements reflecting attitudes about sexual activity, family planning, and parenthood, by timing of survey, Grade 7 Project evaluation, Jamaica, 1995-1997

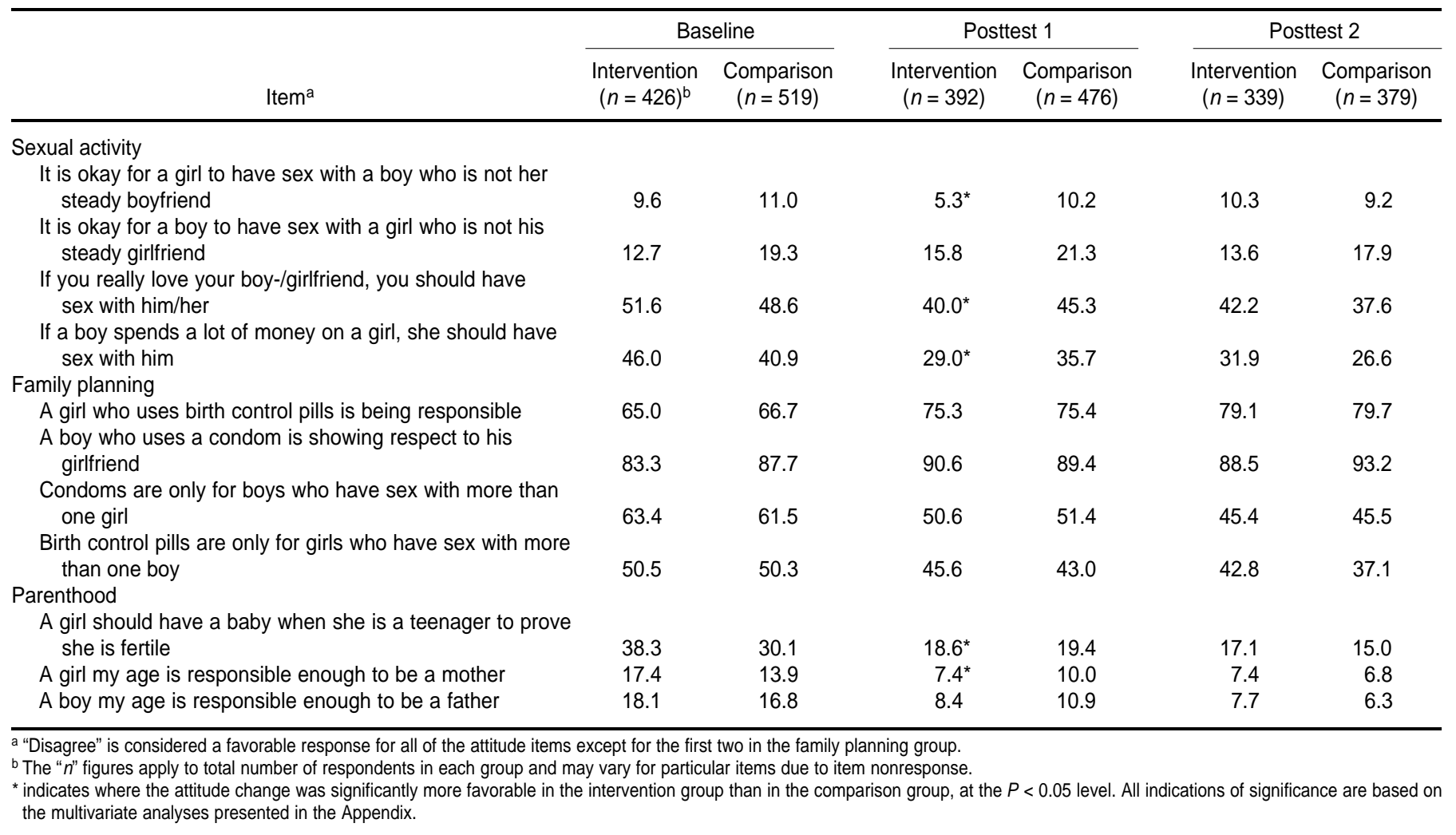

TABLE 4. Among adolescents sexually inexperienced at baseline, percentages in intervention and comparison groups who initiated sexual activity and who used contraception at that first intercourse, by timing of survey, Grade 7 Project evaluation, Jamaica, 1995-1997

\begin{tabular}{|c|c|c|c|c|}
\hline \multirow[b]{2}{*}{ Item } & \multicolumn{2}{|c|}{ Posttest 1} & \multicolumn{2}{|c|}{ Posttest 2} \\
\hline & Intervention & Comparison & Intervention & Comparison \\
\hline Initiated sexual activity during study & $\begin{array}{c}17.5 \\
(n=252)\end{array}$ & $\begin{array}{c}14.9 \\
(n=322)\end{array}$ & $\begin{array}{c}23.3 \\
(n=219)\end{array}$ & $\begin{array}{c}22.5 \\
(n=258)\end{array}$ \\
\hline $\begin{array}{l}\text { Used contraception at that first sexual } \\
\text { intercourse }\end{array}$ & $\begin{array}{c}45.5 \\
(n=44)\end{array}$ & $\begin{array}{c}29.2 \\
(n=48)\end{array}$ & $\begin{array}{c}39.2 \\
(n=51)\end{array}$ & $\begin{array}{c}36.2 \\
(n=58)\end{array}$ \\
\hline
\end{tabular}

A4). However, the Grade 7 Project had no long-term impact on any of the items reflecting parenthood attitudes.

\section{Reproductive behavior}

Sexual activity. About two-thirds of the adolescents in the baseline survey said that they were sexually inexperi- enced. Among these respondents, $17.5 \%$ of the intervention group and $14.9 \%$ of the comparison group reported having sex for the first time between baseline and posttest 1. By posttest 2, among those sexually inexperienced at baseline, $23.3 \%$ of the intervention group and $22.5 \%$ of the comparison group reported having experienced sexual intercourse (Table 4).
Two multivariate logistic regression models were conducted to evaluate the impact of the Grade 7 Project on an adolescent's odds of initiating sexual intercourse subsequent to the start of the Grade 7 Project, while controlling for sociodemographic characteristics and other factors associated with adolescent sexual activity. These models indicated that the project had no significant impact on young adolescents engaging in first sexual intercourse, in either the short term or the long term (Table 5).

Other variables, however, were predictive of initiating sexual activity during the study period. Controlling for other factors, boys were 27 times more likely than girls to report having had sex between baseline and posttest 1 . Boys were also 10 times more likely to say they had had sex in the long term (between baseline and posttest 2). Adolescents who had experimented 
TABLE 5. Results of logistic regression analyses showing likelihood of adolescents reporting experience of first sexual intercourse during study period, Grade 7 Project evaluation, Jamaica, 1995-1997

\begin{tabular}{|c|c|c|c|c|}
\hline \multirow[b]{2}{*}{ Variable $^{a}$} & \multicolumn{2}{|c|}{$\begin{array}{c}\text { Baseline - Posttest } 1 \\
(n=567)\end{array}$} & \multicolumn{2}{|c|}{$\begin{array}{c}\text { Baseline - Posttest } 2 \\
(n=472)\end{array}$} \\
\hline & Odds ratio & $95 \% \mathrm{Cl}^{\mathrm{b}}$ & Odds ratio & $95 \% \mathrm{Cl}$ \\
\hline Sex & $27.02^{*}$ & $14.29-50.00$ & $10.20^{*}$ & $6.25-16.67$ \\
\hline Group & .85 & $0.48-1.51$ & .89 & $0.53-1.49$ \\
\hline Age & 1.01 & $0.63-1.61$ & 1.18 & $0.78-1.78$ \\
\hline Ever-use of alcohol & $1.79^{*}$ & $1.02-3.14$ & $2.42^{*}$ & $1.46-4.00$ \\
\hline Household composition & .84 & $0.47-1.50$ & 1.18 & $0.70-2.00$ \\
\hline Church attendance & $.39^{*}$ & $0.21-0.72$ & .89 & $0.50-1.58$ \\
\hline
\end{tabular}

a Dependent variable coded $1=$ experienced first sexual intercourse during study period, $0=$ did not experience first intercourse during study period. Sex coded $1=$ boy, $0=$ girl. Group coded $1=$ intervention, $0=$ comparison. Ever-use of alcohol coded $1=$ yes, $0=$ no. Household composition coded $1=$ lives with mother and father, $0=$ other. Church attendance coded $1=$ at least once/week, 0 = less than once/week.

${ }^{b} \mathrm{Cl}=$ confidence interval.

* indicates statistical significance at the $P<0.05$ level.

TABLE 6. Results of logistic regression analyses showing likelihood of adolescents using contraception during first sexual intercourse, among adolescents who reported experience of first intercourse during study period, Grade 7 Project evaluation, Jamaica, 1995-1997

\begin{tabular}{|c|c|c|c|c|}
\hline \multirow[b]{2}{*}{ Variable $^{a}$} & \multicolumn{2}{|c|}{$\begin{array}{l}\text { Baseline - Posttest } 1 \\
\qquad(n=91)\end{array}$} & \multicolumn{2}{|c|}{$\begin{array}{l}\text { Baseline - Posttest } 2 \\
\quad(n=108)\end{array}$} \\
\hline & Odds ratio & $95 \% \mathrm{Cl}^{\mathrm{b}}$ & Odds ratio & $95 \% \mathrm{Cl}$ \\
\hline Sex & 0.90 & $0.28-2.86$ & $0.31^{*}$ & $0.12-0.81$ \\
\hline Group & 2.25 & $0.91-5.61$ & 1.06 & $0.41-2.70$ \\
\hline Age & 0.86 & $0.46-1.61$ & $1.27^{\star}$ & $1.06-1.52$ \\
\hline Partner $3+$ years older & $N A^{c}$ & $N A^{c}$ & 1.84 & $0.66-5.16$ \\
\hline Ever-use of alcohol & 0.78 & $0.32-1.90$ & 1.62 & $0.64-4.08$ \\
\hline Household composition & 0.84 & $0.33-2.13$ & 1.40 & $0.51-3.82$ \\
\hline Church attendance & 1.14 & $0.46-2.82$ & 1.21 & $0.43-3.44$ \\
\hline
\end{tabular}

a Contraceptive use coded $1=$ yes, $0=$ no. Sex coded $1=$ boy, $0=$ girl. Group coded $1=$ intervention, $0=$ comparison. Partner $3+$ years older and ever-use of alcohol coded $1=$ yes, $0=$ no. Household composition coded $1=$ lives with mother and father, $0=$ other. Church attendance coded $1=$ at least once/ week, $0=$ less than once/ week.

${ }^{\mathrm{b}} \mathrm{Cl}=$ confidence interval.

${ }^{\mathrm{c}} \mathrm{NA}=$ not applicable; over half the responses were missing.

* indicates statistical significance at the $P<0.05$ level.

with alcohol were 1.8 times more likely than others to say they had experienced sexual intercourse in the short term, and 2.4 times more likely in the long term. In addition, adolescents who attended church weekly were $60 \%$ less likely to have engaged in first sexual intercourse between baseline and posttest 1 than those who attended church less frequently.

Use of contraception. Among adolescents who first experienced sexual posttest 1), adolescents in the Grade 7 Project were more than twice as likely than those in the comparison group to use contraception (Table 6). This relationship fell short of statistical significance at the .05 level, however, with a $P$ value of 0.08 . The Grade 7 Project did not have a significant impact on use of contraception at first intercourse over the long term (by posttest 2).

\section{DISCUSSION}

This study evaluated the impact of a sexuality education program, the Grade 7 Project, on young Jamaican adolescents' initiation of sexual activity and use of contraception at first intercourse, as well as the knowledge and attitudes that have an impact on these behaviors. We measured the effects of the Grade 7 Project at the end of the intervention (short term) and one year post-intervention (long term).

We found that the Grade 7 Project had a positive short-term impact on use of contraception at first intercourse. Although this association fell short of statistical significance at the .05 level, it is worthy of mention given the small sample size of just 91 adolescents. The Grade 7 Project had no statistically significant effect on the adolescents' initiation of sexual activity. However, it had a positive short-term influence on several aspects of the adolescents' knowledge. The project also influenced attitudes about sexuality and pregnancy, perhaps reflecting a higher level of respect and regard for girls.

The impact of the Grade 7 Project was not long lasting. At the end of eighth grade, one year after participating in the project, there was no measurable difference in first-intercourse contraceptive use between adolescents in the Grade 7 Project and those in the comparison group. Nor did the shortterm attitude changes or most of the other improvements persist after the end of seventh grade. These findings were not unexpected; it is unreasonable to expect a school-based intervention of limited duration to have a longterm impact, given the competing 
socioeconomic and cultural forces in Jamaica that encourage early sexual activity and parenthood among adolescents (16-18).

We were unable to evaluate the impact of the Grade 7 Project on sexual activity other than first sexual intercourse. Due to the method of questionnaire administration, asking more questions requiring responses from only sexually experienced adolescents would have made it obvious to all students in the room who was sexually experienced and who was not. Therefore, we were unable to collect information about sexual experiences subsequent to first sexual intercourse and determine if the Grade 7 Project had an impact on, for instance, most recent sexual intercourse.

Modifications might enable the Grade 7 Project to strengthen and perhaps sustain its impact. The project's educator-counselors used largely didactic teaching methods; using more participatory teaching methods might result in a greater influence on participants. Previous research has demonstrated that students remember more from activities that require their active participation than from those which simply require them to listen $(1,19)$. Smaller class sizes might also enhance the project's impact and could facilitate the use of participatory teaching methods. Since resources in Jamaica, as in other developing countries, are extremely limited, holding sessions less frequently than once per week would allow for smaller class sizes without expanding the program's budget.

The prevalence of sexual experience among 12-year-old boys in this study $(64 \%)$ was the same as that reported by older adolescent males (those 15-17 years old) in the 1997 Jamaica Reproductive Health Survey (RHS) (6). It is difficult to validate the accuracy of self-reports of sexual behavior, and previous research indicates that some adolescents report sexual behavior inconsistently (20-22). It is possible that some boys in this study exaggerated the extent of their sexual experience, while girls may have underreported sexual activity. Considerable care was taken to assure study participants of the confidentiality of their responses. Nevertheless, given the sensitive nature of the questions and the sociocultural context of adolescent sexuality in Jamaica, some adolescents may not have reported their sexual behavior truthfully. Focus groups with some study participants revealed that boys perceive strong social encouragement and pressure to be sexually active, while girls who have sex are labeled as having poor moral character (16).

However, we cannot assume either that adolescents in this study reported their sexual experience inaccurately. Early sexual activity among males is not uncommon in Jamaica. In the RHS, $52 \%$ of males and $12 \%$ of females reported experiencing first intercourse before the age of 14 (6). In addition, because the participants in our study were considered at high risk of early sexual activity based on their low socioeconomic class and poor academic achievement, it is not surprising that a high proportion of the boys reported being sexually active at a young age.

There were dramatic differences between boys' and girls' odds of initiating sexual activity and using contra- ception. These results suggest that boys and girls may have very different sexuality education needs and should be the focus of gender-specific interventions. Our findings also suggest that interventions focused on encouraging abstinence may be ineffective among low-income adolescent males in Jamaica. In addition, the high proportion $(64 \%)$ of boys in this study who reported baseline sexual experience suggests that sexuality education should be introduced well before young Jamaicans enter their adolescent years. Further research is needed to explore the development of gender norms among Jamaican adolescents and their effects on sexual attitudes and behavior.

Acknowledgements. The authors would like to express their appreciation to Pamela McNeil of the Women's Centre of Jamaica Foundation; Hugh Wynter, Joan Leitch, Amy Lee, and Jean Munroe of the University of the West Indies; and Karen Hardee, of the Futures Group International, for their assistance and support during study implementation. The authors also thank Cynthia Waszak and Emelita de Leon Wong of Family Health International (FHI) for reviewing this paper and offering helpful comments. Funding for this study was provided by the United States Agency for International Development (USAID) through the Women's Studies Project of FHI. The conclusions expressed in this report are those of the authors and do not necessarily reflect those of the University of the West Indies, Family Health International, or USAID.

\section{REFERENCES}

1. Kirby D, Short L, Collins J, Rugg D, Kolbe L, Howard M, et al. School-based programs to reduce sexual risk behaviors: a review of effectiveness. Public Health Rep 1994;109(3): 339-360.

2. Frost J, Forrest JD. Understanding the impact of effective teenage pregnancy prevention programs. Fam Plann Perspect 1995;27(5):188-195.
3. Franklin C, Grant D, Corcoran J, Miller PO, Bultman L. Effectiveness of prevention programs for adolescent pregnancy. J Marriage Fam 1997;59(3):551-567.

4. Kirby D, Korpi M, Barth R, Cagampang HH. The impact of the postponing sexual involvement curriculum among youths in California. Fam Plann Perspect 1997;29(3):100-108.
5. Mitchell-DiCenso A, Thomas BH, Devlin MC, Goldsmith $\mathrm{CH}$, Willan A, Singer J, et al. Evaluation of an educational program to prevent adolescent pregnancy. Health Educ Behav 1997:24(3):300-312.

6. Friedman JS, McFarlane CP, Morris L. Jamaica reproductive health survey 1997, young adult report. Atlanta, Georgia: United States De- 
partment of Health and Human Services, Centers for Disease Control and Prevention; 1999.

7. Tomlinson M. Situation analysis on family life education in Jamaica and a statement of national family life education policy. Kingston, Jamaica: Marlene Tomlinson and Associates; 1994.

8. United Nations Children's Fund. A strategy for strengthening health and family life education in CARICOM member states. Kingston, Jamaica: UNICEF; 1995.

9. McFarlane CP, Friedman JS, Goldberg HI, Morris L. Jamaica reproductive health survey 1997, final report. Atlanta, Georgia: United States Department of Health and Human Services, Centers for Disease Control and Prevention; 1999.

10. Ansine J. Contraceptives for kids U-16? Government wants to bypass parental consent. The Jamaica Sunday Gleaner 199820 September.

11. Hardee K. Reproductive health case study: Jamaica [POLICY Project working paper]. Washington, D.C.: Futures Group International; 1998.
12. Jamaica, Ministry of Education, Youth and Culture. A statement of national policy for family life education in Jamaica. Kingston: Government of Jamaica; 1995.

13. Barnett B, Eggleston E, Jackson J, Hardee K Case study of the Women's Center of Jamaica Foundation program for adolescent mothers. Research Triangle Park, North Carolina, United States of America: Family Health International; 1996.

14. McNeil P, Olafson F, Powell DL, Jackson J. The Women's Centre in Jamaica: an innovative project for adolescent mothers. Stud Family Plann 1983;13(5):143-149.

15. Jamaica, Ministry of Education. Education statistics 1993. Kingston: Government of Jamaica; 1993

16. Eggleston E, Jackson J, Hardee K. Sexual attitudes and behavior among young adolescents in Jamaica. Int Fam Plann Perspect 1999;25(2): 78-84.

17. Brody EB. Sex, contraception, and motherhood in Jamaica. Cambridge, Massachusetts: Harvard University Press; 1981.
18. Blake J. Family structure in Jamaica: the social context of reproduction. New York: Free Press of Glencoe, Inc.; 1971.

19. Wilson D, Mparadzi A, Lavelle S. An experimental comparison of two AIDS prevention interventions among young Zimbabweans. J Social Psych 1992;132(3):415-417.

20. Lauritsen JL, Swicegood CG. The consistency of self-reported initiation of sexual activity, Fam Plann Perspect 1997;9(5):215-221.

21. Kahn JR, Kalsbeek WD, Hofferth SL. National estimates of teenage sexual activity: evaluating the comparability of three national surveys. Demog 1988;25(2):189-204.

22. Rodgers JL, Billy JOG, Udry JR. The rescission of behaviors: inconsistent responses in adolescent sexuality data. Soc Sci Res 1982;11:280-296.

Manuscript received on 28 April 1999. Revised version accepted for publication on 14 October 1999.

\section{APPENDIX}

TABLE A1. Coefficients from logistic regression analyses showing likelihood of adolescents correctly answering selected knowledge items, Grade 7 Project evaluation, Jamaica, 1995-1997

\begin{tabular}{|c|c|c|c|c|c|c|c|}
\hline \multirow[b]{2}{*}{ Variable $^{\mathrm{a}}$} & \multicolumn{7}{|c|}{ Knowledge item ${ }^{a}$} \\
\hline & $\begin{array}{l}\text { Time during } \\
\text { menstrual } \\
\text { cycle when } \\
\text { pregnancy } \\
\text { most likely }\end{array}$ & $\begin{array}{l}\text { Pregnancy } \\
\text { possible at } \\
\text { first } \\
\text { intercourse }\end{array}$ & $\begin{array}{c}\text { Condoms } \\
\text { protect } \\
\text { against STDs }\end{array}$ & $\begin{array}{l}\text { Birth control } \\
\text { pills protect } \\
\text { against STDs }\end{array}$ & $\begin{array}{l}\text { Sex with virgin } \\
\text { will cure STD }\end{array}$ & $\begin{array}{c}\text { Having sex } \\
\text { while standing } \\
\text { prevents } \\
\text { pregnancy }\end{array}$ & $\begin{array}{c}\text { Drinking } \\
\text { Coke/Pepsi } \\
\text { after sex } \\
\text { prevents } \\
\text { pregnancy }\end{array}$ \\
\hline Group & .36 & -.18 & -.29 & -.15 & .23 & .05 & .13 \\
\hline Sex & $-.79^{*}$ & $-.41^{*}$ & $-1.25^{*}$ & -.22 & $-.79^{*}$ & $-1.02^{*}$ & $-.59^{*}$ \\
\hline Posttest 1 & .35 & $.43^{*}$ & -.08 & .05 & -.01 & -.01 & .19 \\
\hline Posttest 2 & .50 & $.62^{*}$ & -.06 & .40 & $.54^{*}$ & $.38^{*}$ & $.37^{\star}$ \\
\hline Group*Sex & -.01 & .33 & .19 & .24 & .15 & .23 & .26 \\
\hline Group*Posttest 1 & $-1.13^{*}$ & $.39^{*}$ & $.61^{*}$ & .26 & .36 & $.97^{*}$ & $.69^{*}$ \\
\hline Group*Posttest 2 & $-.77^{\star}$ & .26 & .16 & .41 & .26 & $.58^{*}$ & .42 \\
\hline Sex*Posttest 1 & .17 & $-.39^{*}$ & .14 & .30 & $.51^{*}$ & .07 & -.10 \\
\hline Sex*Posttest 2 & .13 & $-.44^{*}$ & .19 & -.16 & -.03 & .07 & -.11 \\
\hline
\end{tabular}

a Knowledge items were coded $0=$ incorrect or don't know. Group was coded $1=$ Grade 7 Project, $0=$ comparison group. Sex was coded $1=$ girl, $0=$ boy

* indicates coefficients that were significant at the $P<0.05$ level. 
TABLE A2. Coefficients from logistic regression analyses showing likelihood of adolescents agreeing with statements reflecting attitudes about sexual activity, Grade 7 Project evaluation, Jamaica, 1995-1997

\begin{tabular}{lcccc}
\hline & \multicolumn{4}{c}{ Statement reflecting sexual activity attitude a } \\
\cline { 2 - 5 } \multicolumn{1}{c}{ Variable } & $\begin{array}{c}\text { Okay for girl to } \\
\text { have sex with } \\
\text { boy who is } \\
\text { not steady } \\
\text { boyfriend }\end{array}$ & $\begin{array}{c}\text { Okay for boy } \\
\text { to have sex } \\
\text { with girl who is } \\
\text { not steady } \\
\text { girlfriend }\end{array}$ & $\begin{array}{c}\text { if you really love } \\
\text { boyfriend/girlfriend, } \\
\text { should have sex } \\
\text { with him/her }\end{array}$ & $\begin{array}{c}\text { If boy spends } \\
\text { money on girl, } \\
\text { she should } \\
\text { have sex } \\
\text { with him }\end{array}$ \\
\hline Group & -.07 & $-.72^{*}$ & .01 & .05 \\
Sex & $-1.55^{*}$ & $-2.17^{*}$ & $-1.65^{*}$ & $-1.27^{*}$ \\
Posttest 1 & .06 & .31 & .01 & -.02 \\
Posttest 2 & -.15 & .06 & $-.57^{*}$ & $-.50^{*}$ \\
Group*Sex & -.78 & .42 & .15 & .26 \\
Group*Posttest 1 & $-.72^{*}$ & .05 & $-.47^{*}$ & $-.61^{*}$ \\
Group*Posttest 2 & .24 & .15 & .05 & .07 \\
Sex*Posttest 1 & -.44 & -.47 & -.21 & -.35 \\
Sex*Posttest 2 & -.11 & -.73 & .13 & $-.51^{*}$ \\
\hline
\end{tabular}

a Sexual attitude items were coded $1=$ agree, $0=$ disagree. Group was coded $1=$ Grade 7 Project, $0=$ comparison group. Sex was coded 1 = girl, 0 = boy.

* indicates coefficients that were significant at the $P<0.05$ level.

TABLE A3. Coefficients from logistic regression analyses showing likelihood of adolescents agreeing with statements reflecting family planning attitudes, Grade 7 Project evaluation, Jamaica, 1995-1997

\begin{tabular}{lcccc}
\hline \multirow{2}{*}{ Variable } & \multicolumn{3}{c}{ Statement reflecting family planning attitude ${ }^{\mathrm{a}}$} \\
\cline { 2 - 5 } & $\begin{array}{c}\text { Girl using birth control pills } \\
\text { is being responsible }\end{array}$ & $\begin{array}{c}\text { Boy using condom shows } \\
\text { respect to girlfriend }\end{array}$ & $\begin{array}{c}\text { Condoms only for boys who have sex } \\
\text { with more than one girl }\end{array}$ & $\begin{array}{c}\text { Pills only for girls who have } \\
\text { sex with more than one boy }\end{array}$ \\
\hline Group & -.10 & -.27 & -.13 & -.07 \\
Sex & .01 & .26 & $-.91^{*}$ & $-.70^{*}$ \\
Posttest 1 & $.41^{*}$ & .41 & $-.45^{*}$ & -.27 \\
Posttest 2 & $.49^{*}$ & $.77^{*}$ & $-.72^{*}$ & $-.50^{*}$ \\
Group ${ }^{*}$ Sex & -.12 & -.34 & -.14 & .10 \\
Group Posttest 1 & .13 & .54 & -.08 & .06 \\
Group*Posttest 2 & .13 & .17 & .09 & .23 \\
Sex*Posttest 1 & -.03 & -.39 & .07 & -.03 \\
Sex*Posttest 2 & .21 & -.36 & -.11 \\
\hline
\end{tabular}

${ }^{a}$ Family planning attitude items were coded $1=$ agree, $0=$ disagree. Group was coded $1=$ Grade 7 Project, $0=$ comparison group. Sex was coded $1=$ girl, $0=$ boy

* indicates coefficients that were significant at the $P<0.05$ level.

TABLE A4. Coefficients from logistic regression analyses showing likelihood of adolescents agreeing with statements reflecting parenthood attitudes, Grade 7 Project evaluation, Jamaica, 1995-1997

\begin{tabular}{|c|c|c|c|}
\hline \multirow[b]{2}{*}{ Variable $^{\mathrm{a}}$} & \multicolumn{3}{|c|}{ Statement reflecting parenthood attitude ${ }^{a}$} \\
\hline & $\begin{array}{l}\text { Girl should have baby as } \\
\text { teen to prove fertility }\end{array}$ & $\begin{array}{l}\text { Girl my age responsible } \\
\text { enough to be mother }\end{array}$ & $\begin{array}{c}\text { Boy my age responsible enough } \\
\text { to be father }\end{array}$ \\
\hline Group & .15 & .29 & .01 \\
\hline Sex & $-.76^{*}$ & $-1.07^{*}$ & $-1.25^{\star}$ \\
\hline Posttest 1 & $-.60^{*}$ & -.37 & $-.58^{*}$ \\
\hline Posttest 2 & $-.86^{\star}$ & $-.84^{*}$ & $-1.15^{\star}$ \\
\hline Group*Sex & $.44^{*}$ & -.06 & .19 \\
\hline Group*Posttest 1 & $-.44^{\star}$ & -.69 & -.43 \\
\hline Group*Posttest 2 & -.21 & -.25 & .09 \\
\hline Sex*Posttest 1 & .04 & $-.01^{*}$ & .22 \\
\hline Sex*Posttest 2 & -.13 & .11 & .11 \\
\hline
\end{tabular}


RESUMEN Pese a su número creciente, son pocos los programas de educación sexual y prevención del embarazo que han sido evaluados en los países en desarrollo. Este estudio, realizado entre 1995 y 1997, evalúa en 945 escolares jamaiquinos de $7^{\circ}$ grado (11 a 14 años de edad)

Evaluación de un programa de educación sexual para adolescentes jóvenes en Jamaica el impacto de un programa escolar de educación sexual, el denominado "Proyecto de $7^{\circ}$ grado", sobre la iniciación de su actividad sexual, el empleo de anticonceptivos durante el primer coito y los conocimientos y actitudes que influyen en sus comportamientos. Utilizando un diseño casi experimental, el estudio midió los efectos del proyecto al final de los nueve meses de intervención (corto plazo) y un año más tarde (largo plazo). El análisis de regresión logística multivariado reveló que el proyecto no tuvo efectos sobre la edad de inicio de la actividad sexual, aunque sí tuvo un impacto positivo a corto plazo sobre el empleo de anticonceptivos en el primer coito $(P=0,08)$; la probabilidad de utilizar anticonceptivos fue dos veces mayor en los adolescentes del grupo sometido a la intervención educativa. El proyecto también tuvo una influencia positiva a corto plazo sobre varios aspectos de los conocimientos y actitudes de los adolescentes hacia la sexualidad y el embarazo. El moderado impacto del proyecto es alentador, dado que los programas escolares de educación sexual de duración limitada raramente tienen impacto a largo plazo y que, además, en Jamaica existen fuerzas socioeconómicas y culturales antagónicas que alientan la sexualidad temprana y la paternidad entre los adolescentes. El empleo de métodos educativos más participatorios y la reducción del número de alumnos por clase podría fortalecer el "Proyecto de $7^{\circ}$ grado" y aumentar su impacto. 